\title{
'OUR FATHER' - IN OR OUT? \\ RELIGIOUS EDUCATION AND SECULAR TENDENCIES IN CROATIAN PUBLIC SCHOOLS IN THE EUROPEAN CONTEXT
}

\author{
Vanja-Ivan SAVIĆ ${ }^{1}$
}

This study discusses religious education in Croatian and European schools, within the overall context of religious symbols in public life. Europe is a vibrant and non-homogenous continent that comprises many cultures and traditions based mostly on Roman law. Various legal cultures and value systems have developed in Europe, which differ due to developmental variations within the European continental system. Religious education is offered in most European countries in various forms. Only three European countries, Albania, Slovenia, and (to some extent) France do not allow religious teaching in public schools. For instance, the crucifix is a part of faith and folklore in Italy, religious celebrations during Christmas, St. Nicholas Day, and Days of the Bread are part of the religious tradition in Croatia (forcibly) broken during the socialist Yugoslavia era, and crosses are present on the national flags of many nations, although their citizens might have forgotten why. Praying and mentioning God, and singing, do not harm anyone but, rather, can serve as a call for friendship, mutual understanding, and peace. It would be useful to create a legal document (e.g. a by-law) that established standards for such public behaviour in schools, which could be followed on a voluntary basis by students, including non-religious children. The Croatian State should organise alternative courses for children who do not follow religious education in order to diminish differences and prevent dissatisfaction and feelings of isolation. Also, education experts should consider the principles of Christian ethics, which secure respect for every citizen. Croatian history and legal traditions as well as International treaties between the Holy See and Croatia secure a place for 'Our Father' and other religious appearances in Croatian public schools. Prayer as well as religious folklore is an important part of religious education and thus an important part of regular curricula. It could be used to build respect for everyone within the Croatian community.

\begin{tabular}{l|l} 
Our Father \\
religion \\
law \\
international treaties \\
religious education \\
public schools
\end{tabular}

values
Croatia
Europe
secularism
Catholic Church
religious community

1 | Associate Professor, Faculty of Law, University of Zagreb, Croatia; Lecturer of Legal Theory, Religion and Legal Systems of the Middle East and North Africa, Human Rights and Croatian Society and Religious Freedoms; vanja.ivan.savic@pravo.hr. 


\section{Introduction - General Tendencies}

In our heavily secularised world, there is no area where worldviews collide on a greater scale than in the education sector, especially in public schools. In the so-called 'developed world' (I will consider all of Europe as such for the purpose of this article), we live in a world of conformity and consumerism, and there is increasingly little space allowed for spiritual life, not just in terms of the time people dedicate to it but also in terms of attitudes towards religiosity itself. Believers are associated with old-fashioned way of living and are often ridiculed for their dedication and piety. At the same time, there are forces within society that do not accept the weakening of their spiritual lives and try to maintain their identity, which includes their religious lives and practices.

One of the most significant rights parents have is the right to educate their children according to their beliefs and worldviews. ${ }^{2}$ The education of children is a critical issue. It is essential to understand that parents' freedom to educate their children as they wish comes from their right to believe and live according to specific values, which deserve to be treated with respect. Belief is an essential part of human existence and metaphysics and defines who you are. The dignity of belief is shared with children and transferred to them within the family as a core unit of society. Of course, there are those who would claim that being secular, agnostic, or atheistic is much more neutral and that religious practices should be reserved for the private sphere. However, being secular, agnostic, or atheist is not neutral at all. This is also a worldview, one that does not acknowledge the presence of the spiritual or divine. It seems erroneous to claim that being agnostic or atheistic allows more neutrality. It is also incorrect to claim that being secular means being neutral, for two reasons. The first reason is that 'secular' in the etymological sense denotes attitudes that have moral, ontological, and axiological value and that are not universal or widely accepted. Second, the claim is not true in the historical sense. Secularity, followed by secularism, appeared as a product of the legal thought of Pope Gregory VII, ${ }^{3}$ who wanted to protect the Church from attacks by feudal lords. Secularism started with completely different intentions and prefixes in terms of source-direction phenomena. This could be called the 'secular moment', ${ }^{\prime}$ the point at which modern church-state relations started to develop. The term 'neutrality' implies a secularised society of which secularity is its main

2 | Article 26 of the Universal Declaration of Human Rights explicitly says '3. Parents have a prior right to choose the kind of education that shall be given to their children' (available at: https://www. un.org/en/about-us/universal-declaration-of-human-rights; accessed 10 April 2021); Article 2 of the Second Protocol of the European Convention on Human Rights says 'No person shall be denied the right to education. In the exercise of any functions which it assumes in relation to education and to teaching, the State shall respect the right of parents to ensure such education and teaching in conformity with their own religious and philosophical convictions' (available at: https:// www.echr.coe.int/documents/convention_eng.pdf; accessed 10 April 2021; Article 14(3) of the Charter of the Fundamental Rights of the European Union says 'The freedom to found educational establishments with due respect for democratic principles and the right of parents to ensure the education and teaching of their children in conformity with their religious, philosophical and pedagogical convictions shall be respected, in accordance with the national laws governing the exercise of such freedom and right' (available at: https:/eur-lex.europa.eu/legal-content/EN/TXT/ HTML/?uri=CELEX:12012P/TXT\&from=EN; accessed 10 April 2021); Hrabar, Dubravka, The Istanbul Convention and the pitfalls of gender perspective, Samizdat, Zagreb, 2018.

3 | See Savić, 2020.

4 | Ibid., p. 274 (Table). 
characteristic: a fair and balanced cooperation but a dissociation of Church (religion) from State.

The modern world became a world of secularism with a secularised society as a characteristic, one that is negative toward church and religiosity. Religion tends to be treated unfairly or, at least, as an entirely private affair. ${ }^{5}$ This leads us to the position that religion is the same as a sports club or friendship society, but it is not. Religion is very different from all other associations. From the psycho-anthropological perspective, religion lies at the core of the existence of humankind and its quest to seek answers to ultimate questions. The second difference is purely legal: Religion has been legally protected due to the historical pogroms that have occurred for religious reasons. Religion is protected widely around the world, from the Universal Declaration of Human Rights to the European Convention of Human Rights and the Declaration on Human Dignity for Everyone Everywhere. ${ }^{6}$

Aggressive secularism wants to erase religiosity from all aspects of public life, especially from schools and universities. The paradox is that those who claim to be most liberal and accept everyone accept only those who think like them. Who will tolerate the intolerant? Who are the intolerant ones in this contemporary world? Are we in an era where parents will have to clash with a system that does not understand the layers of secularity and the historical development of Church-state relations, which work best when conducted through cooperation, mutual understanding, and respect? Liberal states and neo-liberal groups have chosen a path of aggressive secularisation, which changed religion from an ally to a foe. This study discusses recent trends in Croatia. Croatia features higher church attendance and a firmer connection between religion and national identity than is seen in many other European countries, but, as is true everywhere in the West, Croatia is facing problems due to the global influences of conformity, materialism, and decadence. This study argues that, paradoxically, there are two Europes: In one, which has had freedom and where democracy has flourished, church life and religious observance have decreased, not only in the public sphere but also in private life; in the other, countries that suffered from communist repression have perceived religion as a gateway to freedom. As I often say, life in the catacombs made religion flourish in those nations much more strongly than in Western Europe. This provides insight into religious education in Croatia and, to some extent, in the rest of Europe.

\section{Unusual political request in Croatia}

Religion is often used for political purposes. Religions and religious organisations are often affected by situations caused by external, political factors. Religion is often praised or attacked in our deeply polarised world, not out of devotion or hatred, but in order to use it as a tool for political profit.

In early 2018, members of the Croatian Parliament on the political left as well as the Liberals and the Party of Retired People (Građansko-liberalni savez i Hrvatska stranka

5 | Ibid., p. 266 (Table).

6 | Punta del Este Declaration on Human Dignity for Everyone Everywhere written and signed in Punta Del Este, Uruguay in December 2018, on the occasion on the $70^{\text {th }}$ Anniversary of the Universal Declaration on Human Rights; see https://www.dignityforeveryone.org/introduction/; accessed 10 April 2021. 
umirovljenika) proposed that the Croatian government should begin negotiations with the Holy See to amend the so-called 'Vatican Treaties.' ${ }^{7}$ During the Parliamentary debates, the treaty between the Republic of Croatia and the Holy See on education and culture was heavily criticised. ${ }^{8}$ As Staničić pointed out, Liberal MPs proposed a) removing religious education from the public school system, which currently instructs according to the 'values of Christian ethics'. The MPs argued that this violated the principle that a pluralistic civil society cannot be connected and/or bound to any specific moral code, as well as Article 14 of the Constitution..$^{9}$ Also problematic for them was b) the employment of religious teachers and the funding for religious textbooks used in religious education, as well as c) the funding for textbooks used by the Faculty of Theology at the Universities of Zagreb, Đakovo, Makarska, Rijeka, and Split. They also argued that d) the Church could partner with other universities and institutes that are funded by the state but that have no contractual limitations or restrictions (i.e. treaties). ${ }^{10}$

Those claims all argue that confessional religious education conflicts with the provision that all are equal before the law as defined in Article 14 of the Constitution, ${ }^{11}$ and that religious education in public schools discriminates against non-religious students because they do not belong to a specific religious group and are thus subordinated under the dominant Roman Catholic Church. ${ }^{12}$ An additional critique is that teachers of Catholicism-related education are in a better position than are teachers working in the sphere of other religions and/or of other subjects, as the state does not influence the teaching methods they use. This is obviously an inaccurate claim, since all religious communities that operate under an agreement with the Republic of Croatia must offer programs that follow the methodology scientifically determined to be appropriate for the curricula, while respecting the nation's constitution and legal system. In that respect, there are no real differences between the various religious communities in the country.

Another argument is that the Catholic Church has easier access to funding, which is relevant to the publishing of the religious books used as official school textbooks. ${ }^{13}$ This argument has to be examined by considering how religious communities are funded in Croatia. This funding is equitable since it is on a per capita basis. All religious communities (not just Catholic ones) are funded through institutional income, donations, and state budget funds, which are the most important part of their income. ${ }^{14}$ In fact, religious

7| Savić, 2019; Staničić, 2018.

8| Ugovor između Svete Stolice i Republike Hrvatske o suradnji na području odgoja i kulture od 18.12. 1996. This Agreement was the basis for another agreement signed on January 29, 1999 between the Catholic Church and Croatia on religious education, available at: https://hbk.hr/ugovor-o-suradnjina-podrucju-odgoja-i-kulture/, accessed 12 April 2021. To maintain our focus, three other treaties will not be elaborated upon in this paper.

9 | Ibid, Staničić, op .cit. supra footnote 8, p. 400.

10 | Ibid.

11 | Staničić, op. cit., supra footnote 8, p. 402.

12 | See, Ibid., pp. 404-405.

13 | Ibid., pp. 409-410.

14 | Savić, 2019, pp. 257-259. 'Transfers from the State budget may also be put into two categories: i) which are dependent on the characteristics of the particular community and its importance to Croatian society and ii) which will be awarded for specific purpose or need'; see Art. 17. of the Law on the Legal Status of religious communities. Zakon o pravnom položaju vjerskih zajednica [Law on Religious Communities], Narodne Novine (NN), National Gazette of the Republic of Croatia, No. 83/2002, 73/2013, available at: https://narodne -novine.nn.hr/clanci/sluzbeni/2002_07_83_1359. html, accessed on 17 April 2021 
communities enjoy a special tax status. ${ }^{15}$ Most countries, regardless of their model of state-church relations (e.g. state church, complete 'detachment', cooperation), ${ }^{16}$ benefit from and rely heavily on religious institutions in many aspects of life. For example, many religious organisations and religious workers serve in hospitals, penitentiaries, schools, and social work facilities. Therefore, cooperation between church and state in the school system should be considered part of the multi-layered process of mutual collaboration and coexistence in society, which has its roots in Judeo-Christian culture. Until the imposition of communist rule, religion occupied an important place in Croatia's public life and created public morals, which are still present in the fibre of the law today. ${ }^{17}$ Agreements with the Catholic Church formed the basis of all other contracts with the numerous religious communities in the country, and a large majority of those accept their value for all. ${ }^{18}$

It is important to stress that parents are given complete authority over the education of their children according to their moral and ethical values under not only international conventions but also the Croatian Constitution and Judicature of the Constitutional Court. ${ }^{19}$ In that respect, religious education is optional and the decision lies solely with parents.

The Catholic Church used the opportunity provided by the Croatian government's response to the Initiative which was focused on changing the Treatise between Croatia and the Holy See, to implement a religious education program, and Orthodox, Islamic, Jewish, Adventist, evangelical, and Mormon religious organisations followed suit. ${ }^{20}$

15 | Ibid., p. 259.

16 | Those three models are: a) state church, b) separation and c) cooperation; Doe, 2011, pp. 30-39.

17 | For more, see Savić, supra footnote 16, at Chapter 'Historical Background', pp. 240-244; also see Lušić, Tajana, Ugovori između Svete Stolice i Republike Hrvatske, available at: http://www.mvep.hr/ custompages/static/hrv/files/lusic_tajana.pdf, accessed 17April 2021; also see Bajs and Savić, 1998, p. 79-95 (a pioneering article on these issues).

18| The Government of the Republic of Croatia answered this way to the initiative to change the so-called 'Vatican treaties': 'Sve navedeno je iskaz stava Republike Hrvatske koja sukladno Ustavu Republike Hrvatske i odgovarajućim zakonima priznaje opće društveno vrijedan rad Katoličke Crkve u službi građana na kulturnom, odgojnom, društvenom i etičkom polju, što je izrijekom i navedeno u članku 6. Zakona o potvrđivanju Ugovora između Svete Stolice i Republike Hrvatske o gospodarskim pitanjima (Narodne novine - Međunarodni ugovori, broj 18/98). Vlada Republike Hrvatske napominje kako se iz državnog proračuna, na temelju ugovora kojeje Vlada Republike Hrvatske sklopila s vjerskim zajednicama, financiraju i ostale vjerske zajednice u Republici Hrvatskoj', available at: https://vlada. gov.hr/UserDocsImages//2016/Sjednice/2018/05\%20svibnja/99\%20sjednica\%20VRH//99\%20 -\%2021\%20b.pdf, p. 6., accessed on 17April 2021; Summary translation: 'The Croatian Government pointed at the Treaties stipulated between the Republic of Croatia and the Holy See and explained that all religious communities receive funds form the Treasury'.

19 | See supra footnote 2; also 'U skladu s odredbom članka 64. stavka 1. Ustava Republike Hrvatske (Narodne novine br. 85/10 - pročišćeni tekst i 5/14 - Odluka Ustavnog suda Republike Hrvatske) roditelji su dužni odgajati, uzdržavati i školovati djecu te imaju pravo i slobodu samostalno odlučivati o odgoju djece. Slijedom navedene Ustavne odredbe, razvidno je da roditelji samostalno odlučuju u pogledu uključivanja svoga djeteta u izborni predmet pa tako i na vjeronauk bilo koje vjerske zajednice. Svrha organiziranja izborne nastave je omogućavanje slobode u kreiranju odgojno-obrazovnog procesa, proširivanje i produbljivanje znanja i sposobnosti u onom odgojno-obrazovnom području za koje učenik pokazuje posebne sklonosti i pojačan interes'; summarized translation: 'Parents are responsible for raising and educating their children, which also includes decisions about their religious education'; this was published in the National Gazette of the Republic of Croatia No. 85/2010.

20 | Ibid., supra footnote 19, p. 4. 
Although I agree with most of Staničić's statements, I would argue that he is wrong to claim that religious communities operating under agreements with the Croatian state are in a significantly better position than those who are not and that we cannot talk about the equal position of religious communities before the law, even technically, ${ }^{21}$ for two reasons. The ultimate legal question is 'What does it mean for a specific person or group to be equal before the law?' This obviously does not mean expecting the same treatment under different circumstances. For example, a person who is 14 years old or visually impaired will not be allowed to drive a car. One might claim that such a person is not being treated equally before the law, but this is obviously false. In legal theory (jurisprudence), equality before the law means having the same rights under the same (sometimes very similar) circumstances. In our example, the 14-year-old will be able to drive when they are older, and the visually impaired person will be able to drive if they gain their sight. We have to use the same pattern here, especially after the decision of the European Court of Human Rights in Savez Crkava Riječ Života and others v. Croatia, in which the Court decided that Croatia had violated Articles 9 and 14 of the Convention by not granting 'religious community' status to a community that did not have at least 6,000 members or a traditional presence in the country. The decision was handed down because this status had been granted to, for instance, the Bulgarian Orthodox Church, which entered into an agreement with the state but was not native to Croatia and had not requested an agreement. ${ }^{22}$ Because of that decision, all new religious communities can seek equal status when they reach the appropriate stage (e.g. to become 'religious communities', not just 'associations'). This was regulated by the Law on Religious Communities, which allowed the Government of Croatia to sign agreements with religious communities as set out in Article 9 of the law. This law, which had various restrictions, was declared unacceptable. This was the only regulation governing religious communities that mentioned the European Court of Human Rights (ECHR) case (No. 7798/08).

Religious education is often attacked from those on the political left, especially to gain political points and especially before elections. I call these attacks autumn awakenings; every year, another debate starts about religious education in public schools. However, they have gone too far, especially by targeting religious education in public schools, which

21 | See Staničić, op. cit. 8.

22 | European Court of Human Rights Appl. No. 7798/08; see http://www.refworld.org. cases;ECHR,4d5bd2973.html; accessed 18 April 2021: 'In relation to the merits of the claim of a violation of Article 14 in conjunction with Article 9, the Court noted that as the difference in treatment between the Applicants and the other religious communities was not in dispute, it was therefore necessary only for the Court to consider whether such difference in treatment had an objective and reasonable justification, whether it pursued a legitimate aim and whether it was proportionate to the aim pursued. Referring to the decision in Religionsgemeinschaft der Zeugen Jehovas and Others v. Austria (no. 40825/98, 31 July 2008), the Court reiterated that the imposition of criteria which a religious community that already had legal personality had to satisfy in order to obtain special privileges raised delicate questions, "[a]s the State had a duty to remain neutral and impartial in exercising its regulatory power in the sphere of religious freedom and in its relations with different religions, denominations and beliefs". As the Government of Croatia had been unable to provide any meaningful explanation as to why some religious communities satisfied the criteria of belonging to "the European cultural circle" whereas others, including the Applicants, did not, the Court found that such distinction was without "objective and reasonable justification" and, as such, a violation of Article 14 taken in conjunction with Article 9 was found'; Equal Rights Trust, available at: https:// www.equalrightstrust.org/sites/default/files/ertdocs//Savez\%20Crkava_Case\%20Report.pdf, accessed 6 April 2021. 
is voluntary. Another request is to stop funding the Catholic Faculty of Theology and the Faculty of Philosophy and Religious Sciences (Jesuits), as well as the partial funding of Croatian Catholic University. ${ }^{23,24}$ This is especially hostile, given that the Jesuits founded the University of Zagreb (in 1669) and that the Faculty of Theology was prevented from working within that university when the communists came to power after WWII.

\section{3. 'Our Father' and the Days of Bread}

Under pressure from political correctness and Western secularism, many teachers are using generic formulas, especially in matters of religion. For instance, 'Merry Christmas' is replaced with 'Happy Holidays', and 'Happy Easter' is replaced with 'All the best', even though Croatian law establishes official holidays in the country and identifies those that are unmistakably religious in their nature and origin. Christmas, commemorating the birth of Jesus Christ, is clearly a religious holiday; Easter Monday is a celebration of the Resurrection of the Saviour, Jesus Christ, and All Saints Day (November 1) is not the same as the Day of the Dead. Nevertheless, religious and non-religious people both enjoy their non-working days but 'forget', or are ashamed to acknowledge, their religious dimension.

The 'Our Father' is a principal prayer taught in school by religious educators. It is also recited at religious shows for children on St. Nickolas Day and the Days of Bread, when priests visit schools to bless children and bread, the most important symbol of human labour and a sign of prosperity and plenty. However, in recent years, an increasing number of complaints have been made regarding religious ceremonies in schools.

Croatia, like most countries in Europe (e.g. Poland, Italy), follows a cooperation model of church-state relations. Other countries have state churches (e.g. the United Kingdom, Denmark); still others do not recognise the presence of religion within the public sphere, like France. ${ }^{25}$ However, the French Republic has different rules for the departments of Bas-Rhin, Haute-Rhin, and Moselle, as well as for its overseas territories. French secularism retains elements of the Judeo-Christian tradition and Christian (or at least culturally Christian) values, despite the historical hostility of the French Revolution to the Catholic Church. ${ }^{26}$

23 | Prijedlog zaključaka o pokretanju postupka pregovora o izmjenama Ugovora između Svete Stolice i Republike Hrvatske, Predlagatelj: Klub zastupnika GLAS-a i HSU-a, Fonogram rasprave, available at: https://edoc.sabor.hr, accessed on 18 April 2021.

24 | See more in Sokol and Frane, 2018, p. 54.

25 | See Bloss, 2003: 'The history of these nowadays French territories developed differently so that the current legal situation in this region differs significantly from the rest of France. The local law still in force dates back to the law Germinal year X (8 April 1802) that merged a Concordat signed on 15 July 1801 and organic articles of the Catholic and Protestant religion. The Israelite religion was established a couple of years later via a decree from 17 March 1808. Thus, four congregations are officially recognized by the state: the Catholic Church, the Lutheran Church (Confession d'Augsbourg, d'Alsace et de Lorraine), the Reformed Church Alsace-Lorraine and the Israelite religion. The law of the recognized denominations is historically characterized by the principle of non-separation which nowadays exists only in theory. In fact, the public authorities intervene inter alia in the fields of creation and modification of e.g. dioceses, parishes, consistories etc. as well as in the nomination procedures of most of the ministers whose salaries are being paid by the state.' 26 | See more in Savić, 2015, Available at: https://digitalcommons.law.byu.edu/lawreview/vol2015/ iss $3 / 5$. 
If we accept these kinds of secularist critiques, we face an absurd situation in which children undergoing religious education, who are the majority (in some cases, representing over $90 \%$ of the student body), cannot show religious feelings for fear of hurting the minority. ${ }^{27}$ It is dangerous to democratic principles to insist that the values of the majority are wrong, false, and undesirable. The feelings of the minority are also very important and need to be protected, but not in a way that allows the minority to rule over the majority. It is a major mistake to consider secularism, atheism, agnosticism, or even religious neutrality as 'neutral' positions. ${ }^{28}$ The problem is that non-religious people too often see indoctrination in religious ceremonies rather than the values of friendship, sacrifice for the greater good, joy in community, gratitude, and respect for others (while also feeling that buying presents and eating cake at Christmas are somehow not unacceptable).

Most pupils want to participate in religious ceremonies and truly enjoy them. Many non-believing parents and their children also take part in them, not for fear of being isolated, but because they are members of a community that requires mutual respect. Love and respect should go both ways, from majority to minority and vice versa. Only in such a society is it possible to build a healthy environment for all. As Professor Pardon has said, it is important that children develop a conscience and become aware of the path from the tiny seed to the bread on the table. The Days of Bread and public prayer offer children a chance to become aware of that reality, and of the fact that they are blessed to be well-fed and have everything they need. ${ }^{29}$

\section{Grzelak v. Poland and Law as a Just and Fair Balance}

A few words should be said about the Grzelak ${ }^{30}$ case, which is often used as a key case involving the unequal position of children who do not attend religious education. ${ }^{31}$ In that decision, the ECHR ruled that public documents such as school diplomas and transcripts should not contain any information from which religious affiliation could be determined, ${ }^{32}$ as such information could be used prejudicially (e.g. in employment), which would be unacceptable. Religious affiliation should not be a prerequisite for holding public office in Europe.

As Staničić rightly said, the Grzelak case does not endanger the secular state. The ruling affirms that religious education in public schools falls within the scope of the state;

27|Arg. Pažin, Zvonko in Glas Koncila, available at: https://www.glas-koncila.hr/je-liproblematicna-prisutnost-svecenika-na-danima-kruha-u-skoli-razvijanje-vrijednostizahvalnosti-a-ne-indoktrinacija/, accessed on 18 May 2021.

28 I See Weiler's argument in the oral presentation in Lautsi v Italy in front of the Grand Chamber of the ECHR; https://classic.iclrs.org/content/blurb/files/ARTICLE_LAUTSI_PUPPINCK_English_ BYU_Law_Review.pdf; it is also advisable to watch his final argument, available at: https://www. youtube.com/watch?v=ioylyxM-gnM, accessed 18 April 2021.

29 | Pardon, supra footnote 29.

$30 \mid$ European Court of Human Rights; Guide on Article 9 of the European Convention on Human Rights, Freedom of thought, conscience and religion; updated on https://www. echr.coe.int/Documents/Guide_Art_9_ENG.pdf, https://hudoc.echr.coe.int/eng\#\{\%22ite mid\%22:[\%22001-99384\%22]\}, accessed 18 April 2021.

31 | See, Staničić, op. cit., supra footnote 8, p. 401.

32 | Ibid., supra footnote 28. 
the state may decide whether religious education will be introduced and in which form; only indoctrination is impermissible..$^{33}$ It is obvious that the existence of religious education is not predicated on the shape or form of its public expression. Moreover, Croatia's treaties with the Holy See ${ }^{34}$ require that its education system take Christian ethics into account, which clearly shows the connection between Croatian law and the values and tradition of Christian thought. ${ }^{35}$ At the same time, Staničić argues, as do I, that children who do not attend religious education face discrimination. The only difference in our approach is that I consider Staničić's suggestion to omit mention of confessional education from diplomas and transcripts as a change that would discriminate against religious education, which should be treated like any other academic subject. ${ }^{36}$ Those who participate in religious education on a voluntary basis are presumably not ashamed of it and do not mind having it mentioned on their diplomas (even if they are not religious). In addition, the Republic of Croatia is obliged to respect its international treaties, including those signed with the Holy See. The only solution would be to have an alternative course such as 'Ethics', 'Religions,' or 'Cultures of the World', which would be offered along with religious education. That would at least prevent students from sitting in the library or just walking around during religious education classes. A sensible and responsible state should seek a solution to this problem that does not harm religious education but that respects the rights of those who do not believe or who believe but do not wish to attend. The law should always be a good, fair, and just mechanism that seeks to balance the rights of the majority (democratic principle) with the rights of minorities (human rights principle). The human rights principle requires that the law respect both the minority and majority.

\section{Croatia and European Examples}

As mentioned, Croatia conducts its relations with religious groups on the cooperation model. This involves cooperation not just with major religious groups like the Catholic Church but with all religions and religious organisations. Croatia values its religious groups and may serve as a leading example of a country where religious rights and freedoms flourish. The Catholic Church is for historical and cultural reasons the forerunner and leader of the network of agreements Croatia has made with religious organisations (and communities) operating within the Croatian legal system. ${ }^{37}$ This has led to both verti-

33 | Ibid., 403.

34 | Ugovor između Svete Stolice i Republike Hrvatske o suradnji na području odgoja i kulture od 18.12. 1996. As noted, this Agreement was the basis for another agreement signed on January 29 , 1999, between the Catholic Church and Croatia on religious education, available at: https://hbk.hr/ ugovor-o-suradnji-na-podrucju-odgoja-i-kulture/, accessed 18 April 2021.

35 | Ibid., supra footnote 8, p. 401. As Staničić correctly points out by citing Archbishop Nikola Eterović, the term 'ethics' was used rather than 'morals' since morals will always be connected with Catholicism but 'ethics' is an expression of values built upon Christian values, which are more common and acceptable to all Christians, and in a greater sense to the members of other monotheistic religions as well as other citizens; a similar standpoint can be found in Croatian family law theory; Šimović, 2015, 1, str. 235., 256, 262.

36 | See supra footnote 33.

37 | Savić, op. cit., supra footnote 16, p. 250. 
cal and horizontal cooperation, which involve the relation of each particular organisation to the state and ecumenical and interreligious relations, respectively.

Religious education is always a sensitive topic. It is about children, society's most vulnerable group. For that reason, we have to make a special effort to find the right balance for everyone. However, this does not mean that the modern tendency to over-secularize, which has become increasingly aggressive and lacks a proper understanding of the origins of secularity, ${ }^{38}$ must be accepted automatically, without criticism. Everyone has to be aware that we all live in a heterogeneous world and must fine-tune our social relations. Very few European countries have legal systems that include no form of religious education. These few include Albania, Slovenia, and (to a limited extent) France.

France, presumed to be the most secular state, really is not. Religious education exists in various forms in most European countries. Sometimes it is offered as 'just' a course in ethics, connected to the teachings of religion generally or Christianity specifically. The French state funds Catholic education in the departments of Bas-Rhin, Haut-Rhin, and Moselle, and in France's overseas departments. ${ }^{39}$ Many initiatives against religious education, like the one mentioned above, ${ }^{40}$ seem like modern versions of the French Revolution, but now it is not only the Catholic Church that is criticised but all religious communities, and religiosity in general. ${ }^{41}$ It seems that the world is polarised between religious and non-religious. The world is filled with antagonisms, and the quest to balance majority and minority rights may seem a utopian project. However, it may not be. In a study on secularism in Europe and the presence of God in public spaces conducted years ago, I argued that a balance between minority and majority groups could be found in five steps: by a) acknowledging that religion is an important part of cultural life (awareness), b) acknowledging that religion has shaped culture (foundations), c) establishing a minimum number among the majority's prevailing norms in law (democratic principle), d) establishing the maximum possible number of minority rights in law (human rights principle); and e) balancing between minority and majority rights (cohabitation). ${ }^{42}$

\section{Conclusion}

Europe is not homogeneous. Although Europeans share the same basic legal values, derived from our common civil law and Roman law heritage, we have developed in different directions and under various influences. We have to realise that there is nothing wrong with looking at things differently, as long as we respect each other's human dignity and values. Sometimes those values will clash, and we will have to find our way out of the problem in order to be able to live together. The solution is simple. It was described in J. J. H. Weiler's speech in front of the Grand Chamber during the Lautsi v. Italy case: The solution

38 | Savić, 2020; Casanova, 2009, available at: https://berkleycenter.georgetown.edu/publications/ the-secular-and-secularisms. There see more about Pope Gregory VII and his effort to secure a religious life for the Church in the times of strong feudal lords.

39 | Savić, op. cit., supra footnote 8.

40 | See, infra 'Unusual political request in Croatia'.

41 | Savić, op.cit., supra footnote 8.

42 | Savić, op.cit., supra footnote 26, p. 726. 
will be found through tolerance ${ }^{43}$ and mutual respect for different worldviews. However, tolerance must go in both directions. This is a matter of discussion between the majority and minority about the prevailing legal culture of the country, which has to find a way to accommodate the rights of minorities. A minority in one country may be a majority in another just a couple of hundred miles away. Everybody is a minority. The issue of human rights is a two-way street: Democracy would lose its meaning if everything were decided by the minority, but democracy can easily degenerate into tyranny if the majority does not protect minorities. It is a two-way street and requires the ability to hear all arguments.

Religion and religious education do not belong in the Middle Ages, nor are they exclusively for primitive, uneducated people 'at a lower stage of development'. Europe is a mosaic of traditions and cultures, joys, and wounds. It is a continent where people believe in God and laws are derived from and for that belief, where people believe in God and the laws are silent on the matter, and where people do not believe in God but laws protect those who do. Britain has an official state church, the monarch is its head of state, and its national anthem mentions God. Greece's constitution starts by invoking the name of the Holy Trinity. In Denmark, all citizens help fund the Danish National Lutheran Church. In Croatia, most holidays are Catholic. The fact is that contemporary international treaties between the Holy See and the Republic of Croatia secure a place for religious education in Croatian public schools, while also allowing space for all religions.

This does not mean that our way is correct, but it is right for us. The key is to respect one's home and social environment. The key is to throw away bitterness and understand that the 'Our Father' does not harm anyone but merely expresses the values of one's society. Allowing religion in the public square is part of a noble tradition of belonging to a particular history and to a culture that allows space for minorities, including non-believers, and all those who share the same geography and call it 'home'. An understanding of Europe and of the Margin of Appreciation doctrine used by the European Court of Human Rights suggests that the Cross belongs in the classroom in Italy and that Croatian children should pray the 'Our Father' on St. Nicholas Day. No one has an obligation to unify Europe in a way that would erase its history, foundations, or religious identity.

Croatia has to find a way to shape a solution that will provide a complete framework regarding the use of religious symbols in public spaces, especially in schools. This could begin with public forums and conclude with by-laws and clear instructions for school principals and teachers. There is a way to keep tradition alive, while including all pupils.

43 It is advisable to watch the final argument Weiler delivered in front of the European Court of Human Rights in the Lautsi $v$. Italy case; available at: https://www.youtube.com/watch?v=ioylyxMgnM, accessed: 14 March 2021., see footnote 29. 


\section{Bibliography}

| Bajs, D., Savić, V.-I. (1998) Sveta Stolica i Država Vatikanskoga Grada, Zagreb: Pravnik. Bloss, L. (2003) ‘European Law on Religion: Organizational and Institutional Analysis of National Systems and Their Implications for the Future European Integration Process', N.Y. Univ. Law Sch. Jean Monnet Program, Working Paper 13/03.

Casanova, J. (2009) 'The Secular and Secularisms', Social Research, 76(4), 1049-1066, available at: https://berkleycenter.georgetown.edu/publications/the-secular-andsecularisms., accessed: $12^{\text {th }}$ August 2021

Charter of the Fundamental Rights of the European Union available at: https://eur-lex. europa.eu/legal-content/EN/TXT/HTML/?uri=CELEX:12012P/TXT\&from=ENU, accessed: 14th August 2021

Croatian Parliament (phonogram), available at: https://edoc.sabor.hr., accessed: $14^{\text {th }}$ August 2021

Doe, N. (2011) Law and Religion in Europe: A Comparative Introduction. Oxford, UK: Oxford University Press.

Equal Rights Trust, available at: https://www.equalrightstrust.org/sites/default/files/ ertdocs//Savez\%20Crkava_Case\%20Report.pdf., accessed: 16 ${ }^{\text {th }}$ August 2021

European Court of Human Rights Appl. No. 7798/08, available at: http://www.refworld. org.cases;ECHR,4d5bd2973.html, accessed: $20^{\text {th }}$ August 2021

European Court of Human Rights, Guide on Article 9 of the European Convention on Human Rights, Freedom of Thought, Conscience and Religion; updated on https:// www.echr.coe.int/Documents/Guide_Art_9_ENG.pdf, accessed: 20 th August 2021

Glas Koncila [The Voice of the Council, Catholic Weekly], Presence of the Priest on the 'Days of Bread'- Problem or Not? [Je li problematična prisutnost svećenika na danima kruha u školi?, Razvijanje vrijednosti zahvalnosti, a ne indoktrinacija], available at: https://www.glas-koncila.hr/je-li-problematicna-prisutnost-svecenika-na-danimakruha-u-skoli-razvijanje-vrijednosti-zahvalnosti-a-ne-indoktrinacija/., accessed: $20^{\text {th }}$ August 2021

Government of the Republic of Croatia, available at: https://vlada.gov.hr/ UserDocsImages//2016/Sjednice/2018/05\%20 svibnja/99\%20 sjednica\% 20 VRH//99\%20-\%2021\%20b.pdf., accessed: 20 th August 2021

Hrabar, Dubravka, The Istanbul Convention and the pitfalls of gender perspective, Samizdat, Zagreb, 2018.

Lušić, Tajana, Ugovori između Svete Stolice i Republike Hrvatske, available at: http:// www.mvep.hr/custompages/static/hrv/files/lusic_tajana.pdf., accessed: $6^{\text {th }}$ July 2021

Punta del Este Declaration on Human Dignity for Everyone Everywhere written and signed in Punta Del Este, Uruguay in December 2018, on the occasion of the $70^{\text {th }}$ Anniversary of the Universal Declaration on Human Rights (https://www. dignityforeveryone.org/introduction/). 
Savić, V.-I. (2020) 'It Works Better If It Is Not Too Secularized: The Croatian Constitutional Model For Regulating State-Church Relations' in Babie, P., Rochow, N., Scharffs, B. (eds.), Freedom of Religion or Belief, Creating the Constitutional Space for Fundamental Freedoms. Cheltenham: Edward Elgar Publishing.

Savić, V.-I. (2019) 'Ugovori Doprinose Sveopćemu Rastu Vjerskih Sloboda u Hrvatskoj' [Treaties Increase the Level of Religious Freedom in Croatia], Glas Koncila, Catholic Weekly Magazine, No. 10 (March 10).

Savić, V.-I. (2019) 'State and Church in Croatia' in Robbers, G. (ed.) State and Church in the European Union, $3^{\text {rd }}$ Edition. Baden-Baden: Nomos, pp. 257-259.

Savić, V.-I. (2015) 'Still Fighting God in the Public Arena: Does Europe Pursue the Separation of Religion and State Too Devoutly or Is It Saying It Does Without Really Meaning It?' BYU aw Review, 679.

Sokol, T., Stanićić, F. (2018) 'Pravni Položaj Katoličke Crkve Kao Gospodarskog Subjekta U Pravu Europske Unije I Hrvatskom Pravu', ['Legal Position of the Catholic Church as an Economic Subject in EU and Croatian Law'], Selected Papers of the Zagreb Law School, 68(I), p. 54.

Staničić, F. (2018) 'Treba Li Nam Revizija Ugovora Sa Svetom Stolicom?' ['Do We Need a Revision of the Treaties with the Holy See?'], Zbornik Pravnog fakulteta u Zagrebu, 68(3-4).

Weiler, J.H.H., in front of the European Court of Human Rights in Lautsi v. Italy case, Available at: https://www.youtube.com/watch?v=ioyIyxM-gnM., accessed: $20^{\text {th }}$ August 2021

Weiler, J.H.H., in front of the Grand Chamber of the ECHR: https://classic.iclrs.org/ content/blurb/files/ARTICLE_LAUTSI_PUPPINCK_English_BYU_Law_Review.pdf. accessed: $20^{\text {th }}$ August 2021

Ugovor između Svete Stolice i Republike Hrvatske o suradnji na području odgoja i culture, available at: https://hbk.hr/ugovor-o-suradnji-na-podrucju-odgoja-ikulture/. accessed: $19^{\text {th }}$ June 2021

Strasbourg Consortium (Freedom of Conscience and Religion at the European Court of Human Rights), available at: https://www.strasbourgconsortium.org/portal.case. php?pageId=10\#caseId=526., accessed: $19^{\text {th }}$ June 2021

Universal Declaration of Human Rights, available at: https://www.echr.coe.int/ documents/convention_eng.pdf., accessed: $19^{\text {th }}$ June 2021

Zakonopravnompoložajuvjerskihzajednica [Law on Religious Communities], Narodne Novine (NN) [National Gazette of the Republic of Croatia], No. 83/2002, 73/2013, available at: https://narodne -novine.nn.hr/clanci/sluzbeni/2002_07_83_1359.html. 